\title{
Methodological Variations in the Isolation of Genomic DNA from Streptococcus Bacteria
}

\author{
Mônica Moreira ${ }^{1}$, Juliana Noschang ${ }^{1}$, Ivana Froede Neiva ${ }^{1}$, Yanê Carvalho ${ }^{2}$, llma Hiroko \\ Higuti $^{1}$ and Vânia Aparecida Vicente ${ }^{1 *}$ \\ ${ }^{I}$ Departamento de Patologia Básica; Universidade Federal do Paraná; Curitiba - PR - Brasil. ${ }^{2}$ Laboratório de \\ Parasitologia Molecular; Universidade Federal do Paraná; Curitiba - PR - Brasil
}

\begin{abstract}
In this work, genomic DNA of Streptococcus pyogenes, S. mutans and S. sobrinus was isolated using two methods: either using the detergent cetyltrimethylammonium bromide $(C T A B)$ at $65^{\circ} C$; or by applying ultrasound to a mixture of silica and celite in CTAB. The composite method that used ultrasound was the more efficient, allowing the straightforward extraction of genomic DNA from Gram-positive bacteria with good quality and reproducibility.
\end{abstract}

Key words: Key words: Streptococcus, DNA isolation, CTAB, ultrasound

\section{INTRODUCTION}

Pyogenic Streptococcus belonging to Lacefield's $\mathrm{A}, \mathrm{C}$, and $\mathrm{G}$ groups are pathogenic agents of a variety of human and animal diseases (Bert et al., 1997). Streptococcus pyogenes (Streptococcus $\beta$ hemolytic of the A group - GAS) is responsible for causing diseases such as erysipelas, pharyngotonsillitis, and scarlatina (Gonzalez et al., 2003), and some serotypes are associated with nonsuppurative complications such as post streptococcal glomerulonephritis and rheumatic fever (Edwards et al., 2003). Streptococcus of the Mutans group is usually considered as the main etiological agent of dental caries. This group of microorganisms comprises seven distinct species, including $S$. mutans and $S$. sobrinus, which are most commonly associated with human diseases (Hamada and Slade, 1980; Loesche, 1986).
Advances in molecular biology have provided techniques based on PCR (polymerase chain reaction) and DNA sequencing that allow for improvement in the diagnosis and monitoring of diseases caused by the microorganisms, as well as in epidemiological and transmission studies. Bacterial DNA can be amplified by PCR and then sequenced to provide bacterial identification. An efficient DNA extraction method that results in pure, high quality extracts is important for the success of PCR and subsequent DNA sequencing (Smith et al., 2003), as well as other methods used in molecular biology. The demand for molecular diagnostic tests in medical and oral microbiology underscores the need for efficient methods of DNA extraction.

In order to be applicable in laboratory practices, the DNA extraction process should preferably be inexpensive, safe, simple, reproducible, and

*Author for correspondence: vicente@ufpr.br 
adequate to the studied samples. The cell wall of Gram-positive bacteria can be broken by the use of enzymes that degrade peptidoglycans such as the lysozyme and mutanolysin present in the commercial kits (Yano et al., 2002; Old et al., 2006), which cause the method to be expensive. The use of cheaper alternative methods is not always appropriated given the difficulty in breaking the cell wall when some reagents are used, such as phenol-ether (Rantakokko-Jalava and Jalava, 2002).

In this sense, bacterial DNA can be extracted from sera by boiling without using any toxic reagent, overcoming the use of expensive commercial kits for DNA purification (Mayoral et al., 2005). Some researchers have already used cetyltrimethylammonium bromide (CTAB) with good results and considerable cost reduction (Doyle and Doyle, 1987; Petersen and Scheie, 2000; Igarashi et al., 2001), at times being combined with sodium dodecyl sulfate (Dellaporta et al., 1983). In 1956, studies by Slade and Vetter have shown that physical methods such as the used of ultrasound or agitation using glass beads facilitates breaching the cell wall.

The goal of the present study was to assess the efficacy and applicability in daily laboratory routine of two methods for the extraction of Grampositive bacterial genomic DNA, such as $S$. pyogenes, S. mutans, and S. sobrinus.

\section{MATERIAL AND METHODS}

\section{Samples}

Forty isolates of $S$. pyogenes collected from the oropharynx of employees of a food processing company in Curitiba, State of Paraná, where an outbreak of streptococcic pharyngitis occurred in 2004, and 64 isolates of Streptococcus of the Mutans group ( $S$. mutans and S. sobrinus) obtained from saliva samples of 40 individuals belonging to 9 underprivileged families from the suburbs of Curitiba, PR. All Streptococcus isolates were cultivated in brain heart infusion (BHI) broth and incubated at $37^{\circ} \mathrm{C}$ for $24 \mathrm{~h}$. The obtained cultures had approximately $10^{8}$ cells, according to MacFarland's scale.

\section{Total DNA extraction}

1. Protocol using CTAB according to Petersen and Scheie (2000), modified. The culture was centrifuged at $49000 \mathrm{~g}$ for $2 \mathrm{~min}$, and the supernatant was discarded. The bacterial cells were washed twice using a TRIS-EDTA (TE) buffer. A volume of $600 \mu \mathrm{L}$ of CTAB was added to the precipitate, and the entire solution was kept in a heat bath at $65^{\circ} \mathrm{C}$ for $30 \mathrm{~min}$. After the addition of $800 \mu \mathrm{L}$ of a chlorophorm/isoamylic acid solution (CIA, 24:1, v/v), the mix was centrifuged at $49000 \mathrm{~g}$ for $7 \mathrm{~min}$. A total of 450 $\mu \mathrm{L}$ of the supernatant was removed and transferred to another vial, to which an equal amount $(450 \mu \mathrm{L})$ of CIA was added, and the solution was homogenized. After centrifuging at $49000 \mathrm{~g}$ for 7 $\min , 300 \mu \mathrm{L}$ of the supernatant were transferred to another vial, to which 2.5 parts of cold $96 \%$ ethanol were added. The vial was left overnight at $-20^{\circ} \mathrm{C}$. The final step was repeated with cold $70 \%$ ethanol, the mix was centrifuged at $49000 \mathrm{~g}$ for 7 min, and the vial was left open in a wind tunnel chamber to dry the precipitate. The DNA was then suspended in $50 \mu \mathrm{L}$ of ultra pure water and stored at $-4^{\circ} \mathrm{C}$.

2. Protocol using ultrasound combined with silica and celite in CTAB, according to De Hoog et al. (2004), modified: The samples were previously inoculated in BHI broth and incubated for $24 \mathrm{~h}$ at $36^{\circ} \mathrm{C}$. After that the cultures were centrifuged at $49000 \mathrm{~g}$ for $2 \mathrm{~min}$ and the precipitate was transferred to a vial containing a mixture of powdered silica (silica gel, Merk) and celite (2:1) for maceration in $600 \mu \mathrm{L}$ of CTAB buffer. Three 30s pulses of ultrasound (power 70) were applied to it, with 30 s intervals between each pulse, with the vial in ice, using an ultrasonic cell disruptor (Unique ${ }^{\circledR}$ ). After this treatment, $400 \mu \mathrm{L}$ of $\mathrm{CTAB}$ were added to the samples, which were incubated on a heat bath at $65^{\circ} \mathrm{C}$ for $10 \mathrm{~min}$. After reaching room temperature, $1000 \mu \mathrm{L}$ of a CIA solution were added to the mix, which was centrifuged at $49000 \mathrm{~g}$ for $7 \mathrm{~min}$. The supernatant was transferred to another vial, to which an additional $1000 \mu \mathrm{L}$ of CIA was added, and was centrifuged again. Approximately $2000 \mu \mathrm{L}$ of cold $96 \%$ ethanol were added to the supernatant, and the vial was incubated at $-20^{\circ} \mathrm{C}$ overnight for the precipitation of the nucleic acids. After this period, the vial was centrifuged at $49000 \mathrm{~g}$ for $7 \mathrm{~min}$. The supernatant was discarded and the precipitate was washed with cold $70 \%$ ethanol and centrifuged at $49000 \mathrm{~g}$ for $7 \mathrm{~min}$. The ethanol was removed and the tubes remained opened in a wind tunnel chamber until the precipitate was completely dry. The precipitate was resuspended on $50 \mu \mathrm{L}$ of ultra 
pure water and was left at room temperature for $24 \mathrm{~h}$ until being stored at $-4^{\circ} \mathrm{C}$.

\section{Analysis of the DNA extracts}

The DNA was quantified using spectrophotometry $(260 \mathrm{~nm})$, and its integrity was assessed through $0.8 \%$ agarose gel electrophoresis, followed by staining with ethidium bromide and visualization under UV light.

\section{RESULTS AND DISCUSSION}

The results indicated that the efficacy of the DNA extraction of the isolates of $S$. pyogenes as well as the species from the Mutans group ( $S$. mutans and S. sobrinus) were very different. The method using $\mathrm{CTAB}$ at $65^{\circ} \mathrm{C}$ resulted in the extraction of genomic DNA of only one sample of S. pyogenes and 24 samples of isolates from the Mutans group (2.5 and 37.9\%, respectively). However, the method using the combination of silica and celite under ultrasound allowed for the extraction of
$100 \%$ of the isolates of S. pyogenes and $91 \%$ of the Streptococcus from the Mutans group (Fig.1).

The CTAB method was described for fungi and plant DNA extraction, and proved successful also for streptococci (Petersen and Scheie, 2000). Despite the success of some researchers in the isolation of bacterial genomic DNA using the CTAB method (Doyle and Doyle, 1987; Petersen and Scheie, 2000; Igarashi et al., 2001), the action of this detergent at $65^{\circ} \mathrm{C}$ alone was not efficient for breaking the cell wall of the three Streptococcus species tested in the present study. However, the protocol using ultrasound combined with silica and celite in CTAB was much more effective in the extraction of genomic DNA of these Grampositive species. The use of ultrasound increased considerably the efficacy of the breaking of the cell wall, given that the exposition to sonic oscillation of a suspension containing cells of Streptococcus caused their cell walls to disintegrate, releasing the cell contents (Slade and Veter, 1956).

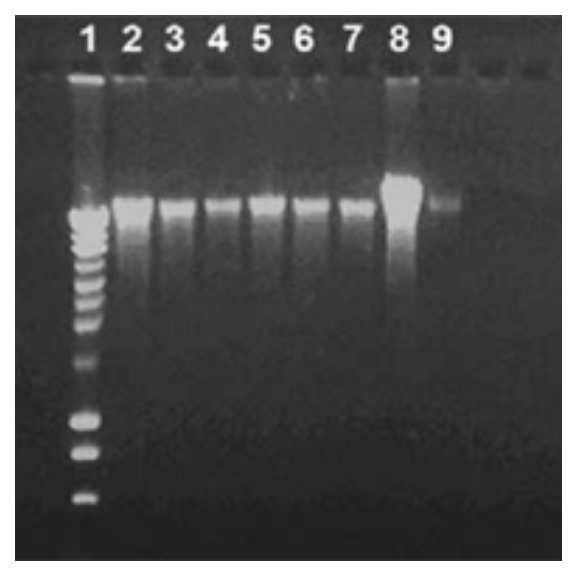

Figure 1 - Extraction of DNA from Streptococcus: 1- ladder 100bp, 2, 3, 4 - S. pyogenes (300ng, 150ng, 100ng, respectively) 5, 6, 7 - S. mutans (200ng, 150ng, 150ng respectively); 8, 9 - S. sobrinus (500ng, 50ng, respectively).

The DNA obtained by using the physical method of maceration with silica-gel together with ultrasound represented a methodological alternative, in which the quantity and quality of the extracted material was sufficient for sequencing or PCR (Fig. 2).

This work demonstrated that molecular detection of bacteria with resistant cell walls in clinical samples could be enhanced by the use of physical cell wall desintegration methods as related by others authors (Rantakokko-Jalava and Jalava, 2002). Results also indicated that no single method was optimal for the detection of all bacteria that might be present in biological fluids, and the use of more than one method should be recommended. Simplified DNA extraction methods for emm typing of group A streptococci (GAS) have been proposed using heating and thawing in association with the use of mutanolysin (Sigma, St. Louis, Mo.) and hyaluronidase (Sigma) (Beall et al., 
1996; Jose and Brahmadathan, 2006). Both methods were shown to be efficient, given that the extracted DNA was used in different molecular methods. However, these methods use enzymes, which increases the costs in comparison with the methods used in the present study.
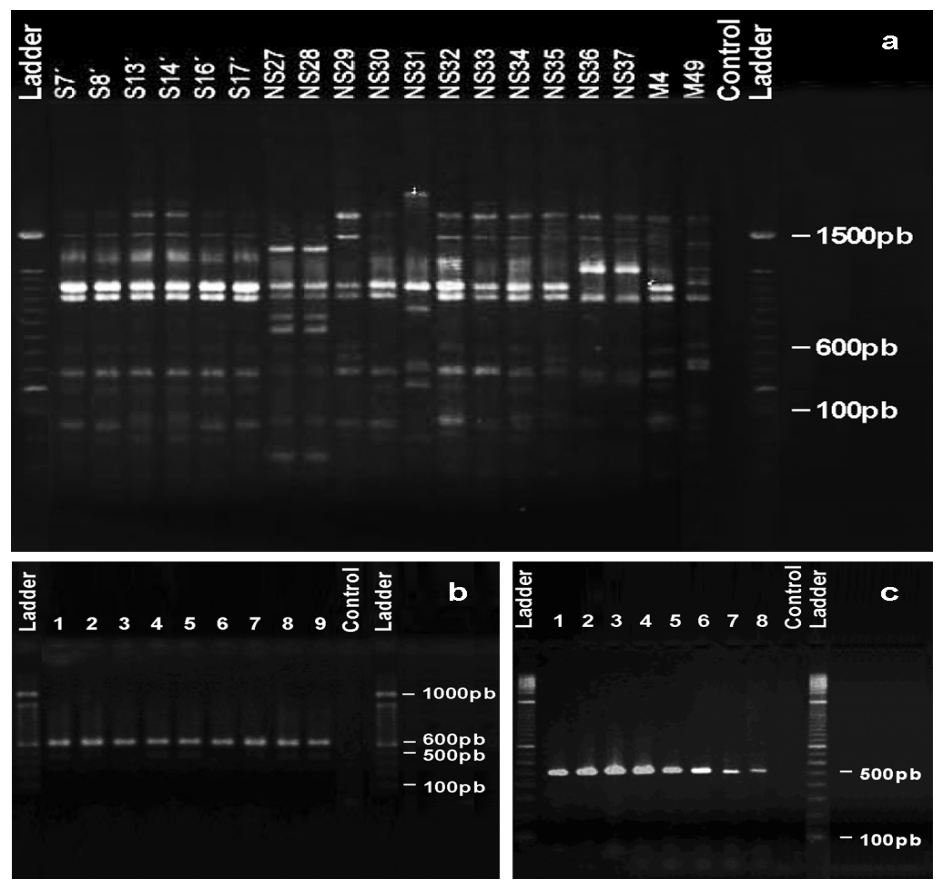

Figure 2 - Representative gel pictures of the bacterial genomic DNA amplified obtained by the method of ultrasound in association with the mixture of silica and celite in CTAB: a) Randomly amplified polymorphic DNA (RAPD) profile of Group A Streptococcus (GAS); b) IGS region amplification profile obtained from genomic DNA of $S$. mutans strains (1-9) c) Sequencing reaction of glycosyltransferase gene (GTS- $\beta$ ) of $S$. mutans strains (1-8).

The advantage of using the physical method as pretreatment without heating or freezing/thawing not even the later use of enzymes, is its simplicity and low cost. In addition, it is useful to standardize these methods for easy and rapid extraction of DNA directly from the isolated colonies of GAS strains and Streptococcus of the Mutans group cultivated in liquid media, facilitating molecular studies (Moreira et al., 2007).

The present results supported the assumption that the method using ultrasound with a mixture of silica and celite in CTAB had good reproducibility, was straightforward to execute, and allowed the extraction of high-quality DNA from Gram-positive cells, and, thus, could be used in molecular biology laboratories.

\section{ACKNOWLEDGEMENTS}

The authors thank Prof Dr Walter Boeger for technical support.

\section{RESUMO}

O gênero Streptococcus encontra-se amplamente distribuído na natureza e algumas espécies constituem a microbiota humana da cavidade bucal, como Streptococcus pyogenes, que pode estar associado a importantes doenças humanas, Streptococcus mutans e Streptococcus sobrinus, relacionados à cárie dental. O DNA genômico destas três espécies foi isolado utilizando-se dois 
métodos, o primeiro utilizando o detergente brometo de cetiltrimetilamônio $(\mathrm{CTAB})$ à $65^{\circ} \mathrm{C} \mathrm{e}$ outro associando ultra-som a uma mistura de sílica e celite em CTAB. O método que possibilitou a extração do DNA genômico das bactérias Gram positivas, com qualidade, boa reprodutibilidade fácil execução foi aquele que utilizou ultra-som associado à sílica e celite em CTAB.

\section{REFERENCES}

Beall, B.; Facklam, R. and Thompson, T. (1996), Sequencing emm-specific PCR products for routine and accurate typing of group A streptococci. Journal of Clinical Microbiology, 4 (34), 953-958

Bert, F.; Branger, C.; Lambert-Zechovsky, N. (1997), Pulsed-field gel electrophoresis is more discriminating than multilocus enzyme electrophoresis and random amplified polymorphic DNA analysis for typing pyogenic streptococci. Curr Microbiol., 34, 226-229

De Hoog, G.S.; Attili-Angelis, D; Vicente, V. A.; Van Den Ende, A. H.; Queiroz-Telles, F. (2004), Molecular ecology and pathogenic potential of Fonsecaeae species. Med Mycol., 5, 405-416

Dellaporta, S. L.; Wood, J.; Hicks, J.B. (1983), A plant DNA minipreparation: versión II. Plant Mol Biol Rep., 1, 19-21

Doyle, J.J.; Doyle, J.L. (1987), A rapid DNA isolation procedure for small quantities of fresh leaf tissue. Phytochemical Bull., 19, 11-15

Edwards, M. L.; Fagan, P. K.; Smith-Vaughan, H.; Currie, B. J.; Sriprakash, K. S. (2003), Strains of Streptococccus pyogenes from severe invasive infections bind Hep2 and HaCaT cells more avidly than strains from uncomplicated infections. J Clin Microbiol., 41, 3936-3938

González-Rey, C.; Belin, A. M.; Jörbeck, H.; Norman, M.; Krovacek, K.; Henriques, B.; Källenius, G.; Svenson, S. B. (2003), RAPD-PCR and PFGE as tools in the investigation of an outbreak of betahaemolytic Streptococcus group A in a Swedish hospital. Comp Immunol Microbiol Infect Dis., 26, 25-35

Hamada, S.; Slade, H. D. (1980), Biology, immunology and cariogenicity of Streptococcus mutans. Microbiol Rev., 44, 331-384
Igarashi, T.; Yano, Y.; Yamamoyo, A.; Sasa, R.; Goto, N. (2001), Identification of Streptococcus salivarius by PCR and DNA probe. Letters in Applied Microbiology, 32, 394-397

Jose, J.J.M. and Brahmadathan,K.N. (2006), Evaluation of simplified dna extraction methods for emm typing of group A Streptococci, Indian Journal of Medical Microbiology, 24 (2), 127-30

Loesche, W. J. (1986), Role of Streptococcus mutans in human dental decay. Microbiol Rev., 50, 353-380

Mayoral, C.; Noroña, M.; Baroni, M.R.; Giani,R.; Zalazar,F. (2005), Evaluation of a nestead-PCR assay for Streptococcus pneumoniae detection in pediatric patients with community-acquired pneumonia. Rev Argent Microbiol, 37 (4), 184-188

Moreira, M.; Vicente, V. A.; Glienke, C. (2007), Genetic variability of Streptococcus mutans isolated from low-income families, as shown by RAPD markers. Brazilian Journal of Microbiology, 38, 729735

Old, L.A.; Lowes, S.; Russel, R.R.B. (2006), Genomic variation in Streptococcus mutans: deletions affecting the multiple pathways of $\beta$-glucoside metabolism. Oral Microbiol Immunol, 21, 21-27

Petersen, F.C.; Scheie, A.A. (2000), Genetic transformation in Streptococcus mutans requires a peptide secretion-like apparatus. Oral Microbiol Immunol, 15, 329-334

Rantakokko-Jalava, K.; Jalava, J. (2002), Optimal DNA isolation method for detection of bacteria in clinical specimens by broad-range PCR. J Clin Microbiol., 40, 4211-4217

Slade, H. D.; Vetter, J. K. (1956), Studies on Streptococcus pyogenes. I. Observations on the microscopical and biological aspects of the disintegration and solubilization of a type 6 strain by shaking with glass beads. J Bacteriol., 71, 236-243

Smith, K.; Diggle, M. A.; Clarke, S. C. (2003), Comparison of commercial DNA extraction kits for extraction of bacterial genomic DNA from wholeblood samples. J Clin Microbiol., 41, 2440-2443

Yano, A.; Kaneko, N.; Hiroshida, I.; Toshikazu, Y.; Hanada, N. (2002), Real time PCR for quantification of Streptococcus mutans. FEMS Microbiology Letters, 217, 23-30.

Received: January 21, 2008; Revised: November 14, 2008; Accepted: October 30, 2009. 